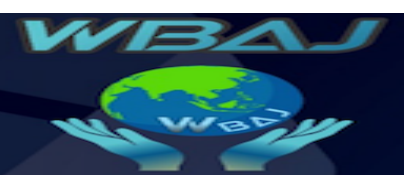

Volume 1 Issue 2, Desember 2019

http:/ / ejournal.unsub.ac.id/index.php/bisnis

\title{
Pengaruh Stres Kerja Terhadap Kinerja Karyawan PT Perkebunan Nusantara VIII Kebun Tambaksari
}

Silvy Sondari ${ }^{1}$

Fakultas Ilmu Administrasi Universitas Subang

silvysondari.gadzali@gmail.com

Iwan Henri Kusnadi ${ }^{2}$

Fakultas Ilmu Administrasi Universitas Subang

Iwanhenri01@gmail.com

Ade Suparman ${ }^{3}$

Fakultas Ilmu Administrasi Universitas Subang

Suparmanade09@gmail.com

\begin{abstract}
Abstrak
Penelitian ini didasarkan pada potensi Perkebunan Teh yang berada di Kabupaten Subang, PT Perkebunan Nunsatara VIII Kebun Tambaksari merupakan salah satu pekebunan yang ada di Kabupaten Subang. Setiap perusahaan tentu memiliki Target dalam mencapai tujuan yang telah ditentukan. Tidak terealisasinya hasil produksi sesuai dengan target yang diharapkan merupakan salah satu permasalahan yang terjadi di PT Perkebunan Nusantara VIII Kebun Tambaksari. hal ini diduga disebabkan oleh stres kerja yang tinggi. Stres kerja bisa berpengaruh Terhadap Kinerja, tetapi tidak selalu berdampak negatif ketika individu dapat mengelola stres tersebut maka stres kerja akan bernilai positif. Metode yang digunakan dalam penelitian ini berangkat dari titik tolak permasalahan yang terjadi sehingga penelitian ini menggunakan metode kuantitatif,dengan pendekatan survei untuk menjelasakan mengenai pengaruh stres kerja dan kinerja karyawan. serta instrumen penelitian yang digunakan dengan menyebarkan kusioner dengan jumlah respoden sebanyak 73 karyawan. Berdasarkan hasil penelitian menunjukan bahwa stres kerja berpengaruh positif dan signifikan terhadap kinerja karyawan PT Perkebunan Nusantara VIII Kebun Tambakasari. Dilihat dari hasil analisis bahwa stres kerja berpengaruh sebesar $30,1 \%$ terhadap kinerja karyawan. Namun pada saat observasi dilakukan bahwa stres kerja bukan merupakan faktor utama yang menyebabkan tidak tercapainya target perusahaan, tetapi iklim kerja yang tidak mendukung dalam proses pekerjaan.
\end{abstract}

Kata kunci : Stes Kerja, Kinerja Karyawan 


\section{Abstract}

This research is based on the potential of tea plantation in Subang Regency, PT Perkebunan Nunsatara VIII Kebun Tambaksari is one of the gardening in Subang Regency. Each company certainly has its Target in achieving a predetermined goal. Unrealized production in accordance with the target is expected one of the problems that occur in PT Perkebunan Nusantara VIII Kebun Tambaksari. This is thought to be caused by high working stress. Working stress can have an effect on performance, but it does not necessarily negatively impact when individuals can manage those stress then work stress will be of positive value. The method used in this research departs from the point of decline of problems that occur so that this research uses quantitative methods, with a survey approach to explain the influence of occupational stress and employee performance. and research instruments used by spreading the questionnaire by a total of 73 respoden. Based on the results of the study showed that the work stress is positive and significant to the performance of employees of PT Plantation Nusantara VIII KebunTambakasari. Judging from the results of the analysis that the work stress affects $30.1 \%$ of employee performance. But at the time of observation is done that work stress is not a major factor that leads to not achieving the target company, but the working climate is not supportive in the job process.

Keywords: Stres work, employee performance

\section{Pendahuluan}

Kinerja merupakan salah satu ukuran atau hasil yang dapat dilihat baik secara individual ataupun institusional. Hal ini menggambarkan bahwa kinerja di dalam suatu perusahaan sangat diperhitungkan. Kinerja karyawan ini mempengaruhi seberapa banyak kontribusi kepada perusahaan. Kinerja yang belum memadai merupakan suatu permasalahan yang sering dihadapi oleh suatu perusahaan dalam usahanya untuk meningkatkan keuntungan yang akan dicapai. Kinerja merupakan hasil kerja secara kualitas dan kuantitas yang dicapai oleh karyawan dalam melaksanakan tugasnya sesuai dengan tanggung jawab yang diberikan kepadanya (Mangkunegara,2014:9). Kualitas kerja yang dimaksud adalah ukuran seberapa baik seorang karyawan dalam mengerjakan apa yang seharunya ia kerjakan sedangkan kuantitas kerja adalah ukuran seberapa lama seorang karyawan dapat bekerja dalam satu harinya. Setiap perusahaan membutuhkan karyawan sebagai tenaga yang menjalankan setiap aktivitas yang ada di dalam perusahaan, karyawan memiliki keterlibatan dalam sebuah perencanaan, proses, sistem dan tujuan yang inginkan dalam perusahaan. Seperti yang dikemukakan Rao dalam Indrasari (2017:53) bahwa kekuatan setiap organisasi adalah terletak pada orang-orangnya, sehingga dengan demikian kinerja dari organisasi tidak dapat dipisahkan dari kinerja yang telah dicapai 
oleh seluruh individu dalam organisasi. Setiap karyawan memiliki potensi yang berbeda-beda. namun perbedaan potensi setiap karyawan dapat di optimalkan bukan hanya dapat meningkatkan kualitas kerja, tetapi dapat juga meningkatkan daya saing perusahaan. Sehingga karyawan mempunyai peran yang sangat besar terhadap keberlangsungan jalan hidupnya suatu perusahaan, sehingga potensi yang menjadi keunggulan karyawan tersebut harus pula dikembangkan kearah yang lebih berguna mencapai tujuan yang optimal. PT Perkebunan Nusantara VIII adalah salah satu badan usaha milik negara dibawah holding perkebunan yang menjalankan berbagai perkebunan seperti teh, karet, sawit, sebagai komoditas utama, juga kina, kopi, dan buah-buahan sebagai komoditas penunjang. Kantor pusat PTPN VIII berlokasi di Bandung dan memiliki 41 perkebunan yang tersebar di 11 kabupaten atau kota seluruh provinsi Jawa Barat dan 2 kabupaten di provinsi Banten. Penelitian ini dilakukan diwilayah kebun Tambaksari yang beralamat di Kasomalang kulon, kecamatan Kasomalang, kabupaten Subang. PT Perkebunan Nusantara VIII kebun Tambaksari saat ini mengelola 2 komoditi utama dengan 5 afdeling yaitu komoditi Teh dengan afdeling Tambaksari, Kasomalang, dan Bukanagara dan komoditi Sawit dengan afdeling Sindangsari dan Serangsari. Dan mengelola 1 pabrik yaitu pabrik pengelolahan Teh hitam CTC di Bukanagara. Berdasarkan informasi yang diperoleh berkaitan dengan kinerja yaitu berupa target dan realiasi produksi teh, dapat dilihat dalam Rekap Produksi Teh 2018 dalam garafik 1.1 sebagai berikut.

\section{Grafik 1.}

Rekap Produksi Teh 2018

Basah 4,40

\begin{tabular}{|c|c|c|}
\hline & Target & Realisasi \\
\hline Desember & 266,986 & 244,830 \\
\hline November & 264,312 & 160,940 \\
\hline Oktober & 224,140 & 141,660 \\
\hline September & 211,825 & 107,670 \\
\hline Agustus & 199,236 & 141,330 \\
\hline Juli & 217,716 & 220,230 \\
\hline Juni & 224,677 & 180,290 \\
\hline Mei & 222,803 & 213,480 \\
\hline April & 211,288 & 206,110 \\
\hline Maret & 217,180 & 147,190 \\
\hline Februari & 209,950 & 167,990 \\
\hline Januari & 207,808 & 184,320 \\
\hline
\end{tabular}


Berdasarkan grafik diatas bahwa realisasi produksi Teh selama 2018 tidak memenuhi target produksi yang ditelah ditetapkan oleh perusahaan, hasil realisasi produksi terendah terjadi pada bulan september dimana total realisasi produksi hanya $107.670 \mathrm{~kg}$ sedangkan target produksi pada bulan tersebut adalah sebesar $211.825 \mathrm{Kg}$. Realisasi produksi tertinggi terjadi pada bulan Desember yaitu $244.830 \mathrm{Kg}$ sedangkan target produksi pada bulan tersebut adalah sebesar 266.986 bahkan tingkat produksi teh selama 2018 mengalami tingkat fluktuatif. hal ini diduga disebabkan oleh stres kerja yang tinggi. Stres kerja merupakan suatu keadaan yang timbul dalam interaksi diantara Individu dengan pekerjaan (Beehr \& Newman dalam wijono, 2018:135). bahwa Keadaan yang dimaksud adalah dimana individu mulai menunjukan atau merasakan suatu beban yang dianggap memberatkan bagi individu dengan beberapa gejala yang menunjukan bahwa individu tersebut mengalami stres kerja. Beberapa gejala yang ditunjukan oleh Karyawan setiap afdeling yaitu hilangnya konsentrasi serta mudah lelah ketika sedang bekerja. selain itu karyawan sudah mulai jenuh dengan pekerjaanya. Stres kerja tentu tidak timbul begitu saja, stres kerja dapat timbul karena tuntutan pekerjaan yang tidak seimbang dengan kemampuan. Kondisi- kondisi yang cenderung mengakibatkan stres dapat ditemukan dalam berbagai situasi pekerjaan dengan reaksi pekerja yang berbeda-beda. Stres pkerja mungkin paling sering dialami kebanyakan karyawan, secara sadar atau tidak itu bisa mempengaruhi kinerja karyawan dalam bekerja. tentunya akan ada dampak yang terjadi ketika seorang karyawan mengalami stres dalam bekerja. Berdasarkan fenomena-fenomena diatas, terdapat indikator permasalahan yang berkaitan dengan kinerja karyawan di PT Pekerbunan Nusantara VIII kebun Tambaksari yaitu target Produksi Teh selama 2018 tidak sesuai dengan realisasi. Kemudian produksi Teh selama 2018 mengalami tingkat fluktuatif.

\section{Kerangka Teori}

\section{a. Manajemen Sumber Daya Manusia}

Pengertian manajemen secara umum memiliki banyak sudut dan pandang dan persepsi yang berbeda-beda. namun pada umumnya Manajemen merupakan salah satu proses dalam mewujudkan tujuan yang diinginkan dalam perusahaan. Menurut Hasibuan,(2012:9) Manajemen yang merupakan ilmu dan seni mengatur proses pemanfaatan sumber daya manusia dan sumber-sumber daya lainya secara efektif dan efesien untuk mencapai tujuan tertentu. Pada dasarnya sumber daya manusia merupakan suatu sumber daya yang dibutuhkan oleh suatu organisasi, karena sumber daya manusia merupakan sumber daya yang berperan aktif terhadap jalanya suatu organisasi dan proses pengambilan keputusan 
(Marjuni,2015:3). Manajemen sumber daya manusia merupakan ilmu dan seni mengatur hubungan dan peranan tenaga kerja agar efektif dan efesien membantu terwujudnya tujuan perusahaan,karyawan, dan masyarakat (Hasibuan, 2012:10). Manajemen Sumber daya manusia merupakan suatu kebijakan dan praktik yang dibutuhkan seseorang yang menjalankan aspek "orang" atau sumber daya manusia dari posisi manajemen, meliputi perekrutan, penyaringan, pelatihan, pengimbalan, dan penilaian (Desser dalam Marjino,2015:9)

\section{b. Stres Kerja}

Stres merupakan salah satu kata yang sering terdengar dari berbagai kalangan baik itu ilmuwan maupun masyarakat umum, namun pengertiannya berbeda-beda. Pada umumnya stres menunjuk pada suatu masalah atau tekanan yang sering dialami setiap orang dalam kehidupan. Sehingga stres mungkin dapat diartikan sebagai kejadian yang tidak menyenangkan atau mungkin dianggap penyakit. Menurut Priyono (2014:1) Stres merupakan pengalaman subyektif yang didasarkan pada persepsi seseorang terhadap situasi yang dihadapinya. dan Menurut Sunyoto dalam Riandy (2016:1063) stres merupakan konsekuensi setiap tindakan dan situasi lingkungan yang menimbulkan tuntutan pisikologis dan fisik yang berlebihan pada seseorang. Pengertian stres ini hampir sama dengan pengertian stres kerja, hanya saja ruang lingkupnya untuk pengertian stres lebih luas. Stres bisa terjadi didalam lingkungan kerja maupun diluar lingkungan kerja. Stres yang dialami didalam lingkungan kerja yaitu stres yang dihadapi oleh karyawan yang terjadi di dalam organisasi atau perusahaan misalnya desakan waktu, tekanan \& beban kerja yang berlebihan. Sedangkan stres yang dialami diluar lingkungan kerja yaitu stres yang dihadapi karyawan yang terjadi diluar organisasi atau perusahaan tetapi tetap berpengaruh pada diri karyawan, misalnya masalah keluarga, pernikahan, keuangan, kesehatan, dan masalah-masalah pribadi lainnya. Menurut Mangkunegara (2011:157) stres kerja merupakan perasaan tertekan yang dialami karyawan dalam menghadapi pekerjaan. Sedangkan Menurut Robbins (2006:793) Stres kerja merupakan kondisi yang muncul dari interaksi antara manusia dan pekerjaan serta dikarakteristikan oleh perubahan manusia yang memaksa mereka untuk menyimpang dari fungsi normal mereka. Menurut Beehr \& Newman dalam wijono (2018:145). Stres kerja merupakan suatu keadaan yang timbul dalam interaksi diantara Individu dan pekerjaan. Keadaan yang dimaksud adalah dimana individu mulai menunjukan atau merasakan suatu beban yang dianggap memberatkan bagi individu dengan beberapa gejala yang menunjukan bahwa individu tersebut mengalami stres kerja. Berdasarkan pendapat-pendapat diatas maka dapat disimpulkan bahwa stres kerja merupakan suatu kondisi atau keadaan dimana seseorang atau karyawan tidak dapat menyeimbangi antara keinginan dengan kenyataan dalam lingkungan pekerjaanya. Dalam penelitian ini Dimensi dan indikator yang digunakan Menurut Robbins dalam Asih (2015:47) dimana dimensi tersebut yaitu external dan internal dari yang bersangkutan dapat 
mempengaruhi reaksi emosional dan psikologis yang terjadi pada situasi dimana tujuan individu mendapat halangan dan tidak dapat mengatasinya. Adapun Dimensi dan indikator stres kerja adalah Aspek eksternal merupakan suatu kondisi yang mempengaruhi psikologis seseorang yang berasal dari luar dirinya adapun indikatornya dan aspek internal dengan indikator merupakan suatu kondisi yang disebabkan oleh adanya konflik atau hambatan yang terjadi dalam diri seseorang dan tidak mampun untuk mengendalikannya.

\section{c. Indikasi dan Gejala-gejala Stres kerja}

Setiap orang akan bereaksi terhadap stres dengan cara yang berbeda-beda, terkadang tidak menyadari bahwa dirinya sedang stres. Menurut Handoko dalam Nuria \& Floresia (2015:25) Indikasi atau gejala-gejala individu yang mengalami stres ditempat kerja antara lain :

1) Bekerja melewati batas kemampuan

2) Keterlambatan masuk kerja yang sering

3) Ketidakhadiran pekerjaan

4) Kesulitan membuat keputusan

5) Kesalahan yang sembrono

6) Kelalaian menyelesaikan pekerjaan

7) Lupa akan janji yang telah dibuat dan kegagalan diri sendiri

8) Kesulitan berhubungan dengan orang lain

9) Kerisauan tentang kesalahan yang dibuat

10) Menunjukkan gejala fisik seperti pada alat pencernaan, tekanan darah tinggi, radang kulit, radang pernafasan.

Menurut Priyonto (2014:4) terdapat tiga katogeri dasar tentang mengapa orang cenderung menilai suatu peristiwa sebagai stres yaitu

1) Psychoanlytic Theory

Kecemasan Neurotik yaitu kecemasan yang tidak proposional terhadap bahaya aktual. Freud yakin bahwa kecemasan neurotik berasal dari konflik bawah sadar didalam seorang individu antara impuls id yang tidak dapat diterima dan batasan-batasan yang diberikan ego dan superego. Menurut teori psikonalitik, kita semua memiliki suatu konflik bawah sadar.

2) Behavioral Theory

Freud dalam Priyonto (2014: 4) memandang konflik bawah sadar sebagai sumber internal respons stres. Ahli behavioris telah menfokuskan pada cara dimana individu belajar mengasosikan respons stres dengan situasi tertentu.

3) Cognitivie Theory

Ketidakberdayaan yang dipelajari yang diajukan oleh Abramson dkk dalam Priyonto (2014: 5) memfokuskan pada satu tipe gaya kepribadian. Para peneliti tersebut berpendapat bahwa jika seseorang mempertalikan peristiwa negatif dengan penyebab internal pada dirinya (ini salah saya) mereka paling 
mungkinan menunjukan respons ketidakberdayaan dan terdepresi terhadap peristiwa negatif.

Stres tidak datang begitu saja tentu ada penyebab kenapa setiap individu tersebut dapat mengalami stres bekerja sama. Hal ini dikemukakan oleh Sopiah dalam Wijaya (2017 : 285) Stressor merupakan penyebab stres, terdapat banyak stressor dalam organisasi dan aktivitas hiduplainnya. Stressor yang berhubungan dengan pekerjaan terbagi menjadi empat tipe utama, yaitu:

1) Lingkungan Fisik

2) Beberapa stressor ditemukan dalam lingkungan lingkungan fisik pekerjaan, seperti terlalu bising, kurang baiknya penerangan ataupun resiko keamanan. Stressor yang bersifat fisik juga kelihatan pada setting kantor, termasuk rancangan ruang kantor yang buruk, ketiadaan privasi, lampu penerangan yang efektif dan kualitas udara yang buruk.

3) Stres karena Peran dan Tugas

4) Stressor karena peran-tugas termasuk kondisi dimana para pegawai mengalami kesulitan dalam memahami apa yang menjadi tugasnya, peran yang dia mainkan dirasa terlalu berat atau memainkan berbagai peran pada tempat mereka bekerja.

\section{d. Jenis - Jenis Stres Kerja}

Menurut Quick dan Quick dalam Putra (2018:13) ada 2 jenis stres yaitu

a) Eustress, yaitu hasil dari respon terhadap stres yang bersifat sehat, positif, dan konstruktif (bersifat membangun). Hal tersebut termasuk kesejahteraan individu dan juga organisasi yang diasosiasikan dengan pertumbuhan, fleksibilitas, kemampuan adaptasi, dan tingkat performance yang tinggi.

b) Distress, yaitu hasil dari respon terhadap stres yang bersifat tidak sehat,negatif, dan destruktif (bersifat merusak). Hal tersebut termasuk konsekuensi individu dan juga organisasi seperti penyakit kardiovaskular dan tingkat ketidakhadiran (absenteeism) yang tinggi, yang diasosiasikan dengan keadaan sakit, penurunan, dan kematian.

\section{e. Kinerja Karyawan}

Kinerja berhubungan erat dengan pencapaian tujuan perusahaan, karena karyawan merupakan salah satu faktor utama bagi perusahaan dalam mencapai tujuan yang telah ditetapkan. Menurut Kusriyanto, dalam Mangkunegara (2014:9) Kinerja karyawan merupakan perbandingan hasil yang dicapai dengan peran serta tenaga kerja persatuan (waktu lazimnya perjam). Menurut Bastian, dalam Fahmi (2015:2) kinerja merupakan gambaran mengenai tingkat pencapaian pelaksanaan suatu kegiatan/program/kebijaksanaan dalam mewujudkan sasaran, tujuan, misi, dan visi organisasi yang tertuang dalam perumusan skema strategis (startegic Planning) suatu organisasi. Menurut A.A. Anawar Prabu Mangkunegara (2014:9) Kinerja karyawan merupakan hasil kerja secara kualitas dan kuantitas yang dicapai 
oleh seorang karyawan dalam melaksanakan tugasnya sesuai dengan tanggung jawab yang diberikan kepadanya. Adapun yang dimaksud dengan kualitas kerja adalah ukuran seberapa baik seorang karyawan dalam mengerjakan apa yang seharunya ia kerjakan sedangkan kuantitas kerja adalah ukuran seberapa lama seorang karyawan dapat bekerja dalam satu harinya. Berdasarkan beberapa definisi diatas bahwa kinerja merupakan suatu hasil kerja yang diperoleh karyawan (individual atau kelompok) dalam dalam menyelesaikan pekerjaanya sesuai dengan waktu yang telah ditentukan oleh perusahaan.

Menurut Mathis dalam Filanisa (2017:19) merupakan hasil pekerjaan yang dicapai karyawan berdasarkan dimensi kerja, berikut dimensi serta indikatornya :

1) Kualitas hasil kerja

Hasil Kerja yang dicapai oleh pegawai yang sesuai dengan syarat-syarat ketentuan dari perusahaan. Indikatornya adalah ketelitian hasil kerja.

2) Kuantitas hasil kerja

Jumlah hasil kerja yang diselesaikan oleh pegawai. Indikatornya adalah hasil pencapaian kerja

3) ketepatan waktu

Ketepatan waktu sesuai dengan standar yang dicapai pegawai dalam menyelesaikan pekerjaan yang telah diberikan perusahaan. Indikatornya adalah kecepatan waktu dalam bekerja.

4) Kehadiran

Karyawan memenuhi atau tidaknya standar nilai kehadiran sesuai dengan aturan atau tata tertib yang berlaku dalam organisasi, Indikatornya adalah pencapaian kehadiran.

5) Dampak Interpersonal

Hasil hubungan karyawan dalam saat bekerja sama, Komunikasi, \& peran serta dalam perusahaan. Indikatornya adalah bekerja sama, komunikasi, dan peran serta.

Salah satu cara yang dapat digunakan untuk melihat perkembangan perusahaan adalah dengan cara melihat hasil penilaian kinerja. Penilaian kinerja merupakan suatu penilaian yang dilakukan pihak manajemn perusahaan baik para karyawan maupun manajer yang selama ini telah melakukan pekerjaanya (Fahmi, 2015:65). Suatu perusahaan perlu melakukan penilaian kinerja untuk mengningkatkan kualitas kinerja perusahaan. Seperti yang dikemukakan Griffin dalam Fahmi (2015:67) bahwa kinerja karyawan seharusnya dievaluasi secara berkala karena berbagai alasan. Untuk melakukan kinerja dibutuhkan metode penilian yang memiliki tingkat dan analisa yang representatif.

Dua kategori dasar dari metode penilaian yang sering digunakan dalam organiasi yaitu

a) Metode objektif merupakan metode yang menyangkut sejauh mana seseorang bisa bekerja dan menunjukan bukti kemampuan ia bekerja sesuai dengan kemampuan yang dimilikinya. 
b) Metode pertimbangan adalah metode penilaian berdasarkan nilai rangking yang dimiliki seseorang karyawan, jika ia memiliki nilai rangking yang tinggi maka artinya ia memiliki kualitas kerja yang bagus dan begitu pula sebaliknya.

Menurut Dharma dalam Wartono (2017:45) tujuan penilaian kinerja sebagai berikut

1) Kedisiplinan

Penilaian disiplin dalam mematuhi peraturan-peratutan yang ada dan melakukan pekerjaan sesuai intruksi yang diberikan kepadanya.

2) Kreatifitas

Penilaian kemampuan karyawan dalam mengembangkan kreativitas untuk menyelesaiakan pekerjaan.

3) Pertanggung Jawaban

Pertanggung jawaban, apabila standard dan sasaran digunakan sebagai alat pengukur pertanggung jawaban, maka dasar untuk pengambilan keputusan kenaikaan gaji atau upah, promosi dan penugasan khusus dan sebagainya adalah kualitas hasil pekerjaan yang bersangkutan.

4) Pengembangan

Jika standard dan sasaran digunakan sebagai alat untuk keperluan pengembangan, hal itu mengacau pada dukungan yang diperlukan pengembangan, hal itu mengacu pada dukungan yang diperlukan karyawan dalam melaksanakan pekerjaan mereka. Dukungan itu berupa pelatihan, bimbingan atau bantuan lainnya.

\section{Metode Penelitian}

Penelitian ini menggunakan metode kuantitatif, metode ini lebih menitikberatkan pada aspek pengukuran secara obyektif sehingga penelitian ini berangkat dari masalah yang menjadi titik tolak dari penelitian yang sudah jelas data-datanya. Jenis Penelitian menggunakan penelitian Eksplanasi, untuk menjelaskan suatu generalisasi sampel terhadap populasinya atau menjelaskan hubungan, perbedaan, pengaruh satu variabel dengan variabel lainnya (Bungin,2005:46). Penelitian ini menggunakan pendekatan survei, suatu survei yang digunakan untuk menjelaskan pengaruh antara dua variabel atau lebih melalui pengujian hipotesis, survei dilakukan dengan cara mengambil populasi dengan menggunakan kuesioner sebagai alat pengumpulan data.

\section{Hasil dan Pembahasan}

PT Perkebunan Nusantara VIII Kebun Tambaksari merupakan salah satu badan usaha milik negara dibawah holding perkebunan yang menjalankan berbagai perkebunan seperti teh, karet, sawit, sebagai komoditas utama, juga kina, kopi, dan buah-buahan sebagai komoditas penunjang.Kantor pusat PTPN VIII berlokasi di Bandung dan memiliki 41 perkebunan yang tersebar di 11 kabupaten atau kota seluruh 
provinsi jawa barat dan 2 kabupaten di provinsi Banten. Kebun Tambaksari merupakan gabungan dari 3 Afdeling milik pemerintah kolonial Belanda yaitu Kebun Bukanagara (1902), Kebun Kasomalang (1906) dan Kebun Tambakan (1922). beberapa tahun kemudian kebun sarireja dan kebun sindangsari juga di gabungkan menjadi Perkebunan Tambaksari. Pada Tahun 1950 diahlihkan ke Pamanukan dan Tjiasem Lands ( P \& T) miliki kerajaan Inggris. Kemudian pada tahun 1964 dinasionalisasikan oleh Pemerintah Republik Indonesia menjadi BUMN. Setelah itu perkebunan Tambaksari mengalami beberapa kali pengalihan pengolahan, mulai dari PPN Dwikora IV (1964 - 1970), PP Subang (1970 - 1973), PT Perkebunan XXX (1973 - 1979), PT Perkebunan XIII (1979 - 1995) dan PT Perkebunan Nusantara VIII (1995 - Sekarang). Penggabungan Afdeling Bukanagara, Kasomalang \& Tambakan terjadi pada tahun 1979, saat diambil alih oleh PT Perkebunan XIII. Pabrik Teh Tambaksari yang lama berdiri sejak 1922 berproduksi dengan menggunakan system Ortodoks sampai tahun 1986. Pada tahun 1986 pihak perusahaan melakukan pergantian mesin-mesin pengolahan Teh dari Sistem Ortodoks ke Sistem CTC untuk meningkatkan hasil produksi Teh hitam kering. Pada tahun 1955, PTP VIII Kebun Tambaksari bergabung kedalam BUMN Wilayah Jawa Barat. Pada Tahun 1996, PT Perkebunanan Nusantara VIII sampai dengan sekarang. Saat ini PT Perkebunan Nusantara VIII kebun Tambaksari mengeola 3 Afdeling Teh yaitu Afdeling Tambaksari, Afdeling Kasomalang dan Bukanagara. Sedangkan komoditi sawit yaitu Afdeling Sindangsari dan Serangsari. PT Perkebunan Nusantara VIII Kebun Tambaksari terletak pada ketinggian 480 - 1200 $\mathrm{m}$ diatas permukaan laut dengan suhu maksimum $28 \mathrm{C}$ dan suhu minimum $15 \mathrm{C}$. Ratarata hujan didaerah ini berksar 2000-5000 mm pertahun daengan kelembaban $60-90 \%$. Secara umum perkebunan Tambaksari bertopografi datar dan bergelombang. Jenis tanahnya berupa tanah vulkanik dan andosol dengan PH berkisar antara 5.5 - 6.5 Perkebunan Tambaksari terletak dibeberapa Desa dan tiga kecamatan yaitu Desa Tambakan, Desa bunihayu kecamatan jalancagak, Desa kasomalang wetan, Desa kasomalang kulon di kecamatan kasomalang dan Desa cupunagara kecamatan cisalak. Pabrik pengeolahan bukangara terletak di desa Cupungara kecamatan cisalak dan kantor induknya terletak di Desa kasomalang Kulon kecamatan kasomalang. Adapun, topografi kebun Tambaksari sebagai berikut :

1. $0 \circ-8 \circ=603.788$ afdeling kasomalang dan Tambaksari

2. $25-45=1162.529$ afdeling Bukanagara

\section{a. Konversi Data}

Hasil dari jawaban respoden mengenai pernyataan variabel stres kerja dan kinerja karyawan merupakan data ordinal sehingga harus dirubah terlebih dahulu menjadi data interval. Konversi data ordinal ker interval ini menggunakan Method Of Successive Interval (MSI). Untuk mengolahnya menggunakan aplikasi STATCAL 2019 adapun Hasil dapat dilihat di lampiran. 


\section{b. Validitas dan Relibilitas}

Dalam Penelitian ini instrumen yang digunakan adalah kuesioner, kuesioner berisi mengenai pernyataan yang berkaitan dengan indikator variabel stres kerja dan variabel kinerja. Instrumen yang digunakan dalam penelitian ini dimaksud untuk menghasilkan data dengan menggunakan skala likert.

\section{c. Hasil analisis Statistik}

\section{c.1 Hasil Uji Regersi}

Digunakan untuk mengetahui pengaruh variabel stres kerja terhadap variabel kinerja. Dasar pengambilan keputusan dalam uji regresi sederhana mengacu pada dua hal yakni dengan membandingkan nilai $t$ hitung dengan $t$ tabel atau dapat membandingkan nilai signifikasi dengan profitabilitas 0,05 . perhitungan menggunakan SPSS versi 23 dengan analisi regresi sederhana, adapun hasil perhitungan sebagai berikut

Tabel 2

Analisis Regresi Sederhana

Coefficients ${ }^{a}$

\begin{tabular}{|c|c|c|c|c|c|}
\hline \multirow[b]{2}{*}{ Model } & \multicolumn{2}{|c|}{$\begin{array}{r}\text { Unstandardized } \\
\text { Coefficients }\end{array}$} & \multirow{2}{*}{\begin{tabular}{|c}
$\begin{array}{c}\text { Standardize } \\
\mathrm{d} \\
\text { Coefficie } \\
\text { nts }\end{array}$ \\
Beta \\
\end{tabular}} & \multirow[b]{2}{*}{$\mathrm{T}$} & \multirow[b]{2}{*}{ Sig. } \\
\hline & $\mathrm{B}$ & Std. Error & & & \\
\hline $1 \quad$ (Constant) & 9,581 & 1,935 & & 4,950 &, 000 \\
\hline Stres Kerja &, 579 & ,092 & ,597 & 6,269 & ,000 \\
\hline
\end{tabular}

a. Dependent Variable: Kinerja Karyawan

Sumber : Hasil olahan spss versi 23

Berdasarkan tabel diatas, dapat dijelaskan bahwa persamaan regresi antara pengaruh stres kerja terhadap kinerja karyawan dilakukan analisis koefisien regresi dapat disusun sebagai berikut:

$$
\mathrm{Y}=\mathrm{a}+\mathrm{Bx} \quad \mathrm{Y}=1,935+0,579 \mathrm{x}
$$

\section{Dimana :}

$\mathrm{X}=$ Stres Kerja $\mathrm{Y}=$ Kinerja Karyawan

a Nilai Konstanta menunjukan bahwa jika tidak ada pengaruh stres kerja (x) maka nilai Konsisten Kinerja Karyawan sebesar 1,935

b Nilai Koefisien Regresi sebesar 0,548 artinya bahwa penambahan 1\% = tingkat stres Kerja maka akan meningkat sebesar 0,579 
Karena nilai koefisen regresi bernilai positif maka dengan demikian dapat dikatakan bahwa stres kerja berpengaruh postif terhadap kinerja karyawan sehingga persamaan regresinya $Y=1935+0,579 \mathrm{X}$

Adapun yang menjadi dasar pengambilan keputusan dalam analisis regresi dengan melihat nilai signifikasi. Berdasarkan hasil spss pada tabel 4.2 bahwa nilai signifikasi 0,00 lebih kecil dari nilai probabilitas 0,05 sehingga dapat disimpulkan bahwa Ho ditolak dan Ha diterima, yang berarti bahwa "ada pengaruh stres kerja terhadap kinerja karyawan PT Perkebunan Nusantra VIII Kebun Tambaksari".

A. Hasil Uji Hipotesis Regresi Parsial dan simultan

Pengujian T ini digunakan untuk mengetahui tingkat signifikan pengaruh variabel stres kerja terhadap variabel kinerja karyawan secara parsial untuk pengambilan keputusan uji hipotesis sebagai berikut

Tabel 3

Uji Pasial

Coefficients ${ }^{a}$

\begin{tabular}{|c|c|c|c|c|c|}
\hline \multirow[b]{2}{*}{ Model } & \multicolumn{2}{|c|}{$\begin{array}{c}\text { Unstandardized } \\
\text { Coefficients }\end{array}$} & $\begin{array}{c}\text { Standardize } \\
\mathrm{d} \\
\text { Coefficie } \\
\text { nts }\end{array}$ & & \\
\hline & B & Std. Error & Beta & $\mathrm{t}$ & Sig. \\
\hline (Constant) & 9,581 & 1,935 & & 4,950 & ,000 \\
\hline Stres Kerja &, 579 & ,092 & ,597 & 6,269 & , 000 \\
\hline
\end{tabular}

a. Dependent Variable: Kinerja Karyawan

Sumber : Hasil olahan spss versi 23

Berdasarkan tabel 4.5 diatas, diperoleh nilai signifikasi untuk pengaruh stres kerja $(\mathrm{x})$ terhadap kinerja karyawan adalah $0,00<0,05$ maka terdapat pengaruh variabel $X$ terhadap variabel $Y$ selanjutnya thitung sebesar 4,950 dan selanjutnya menentukan $t_{\text {tabel, }}$ tabel distribusi t dicari pada $a=0,1$ dengan derajat bebas $\mathrm{N}-2$ yaitu $73-2=71$, maka tabel diperoleh 1.293 oleh karena thitunglebih besar dari tabel yaitu 4,950>1.292 maka Ho ditolak, artinya terdapat pengaruh yang signifikan antara stres kerja terhadap kinerja karyawan PT Perkebunan Nusantara VIII kebun Tambaksari. Pengujian f dilakukan untuk mengetahui Apakah variabel stres kerja secara simultan berpengaruh signifikan terhadap variabel dependen. Dasar pengambilan keputusan uji $\mathrm{F}$ jika nilai sig $<0,05$ atau Fhitung $>$ Ftabel mak terdapat pengaruh variabel $x$ secara slimutan terhadap variabel $\mathrm{Y}$ dan jika sig nilai sig $>0,05$ atau $\mathrm{f}$ hitung $<\mathrm{f}$ tabel maka tidak terdapat pengaruh variabel $x$ secara simultan terhadap variabel $Y$ rumus untuk mendapatkan nilai $\mathrm{F}$ tabeladalah $\mathrm{F}$ tabel $\mathrm{f}(\mathrm{k} ; \mathrm{n}-\mathrm{k})=\mathrm{f}(1 ; 72)=3,97$. Adapun perhitungan menggunakan spss versi 23 sebagai berikut

Tabel 4

Uji Simultan 
ANOVA $^{\mathrm{a}}$

\begin{tabular}{|c|c|c|c|c|c|}
\hline Model & $\begin{array}{l}\text { Sum of } \\
\text { Squares }\end{array}$ & $\mathrm{df}$ & $\begin{array}{l}\text { Mean } \\
\text { Square }\end{array}$ & $\mathrm{F}$ & Sig. \\
\hline Regression & 285,225 & $\overline{1}$ & 285,225 & 39,302 &, $000^{\mathrm{b}}$ \\
\hline Residual & 515,263 & 71 & 7,257 & & \\
\hline Total & 800,488 & 72 & & & \\
\hline
\end{tabular}

a. Dependent Variable: Kinerja Karyawan

b. Predictors: (Constant), Stres Kerja

Sumber : Hasil olahan spss versi 23

Berdasarkan tabel 4.6 nilai signifikasi untuk stres kerja terhadap kinerja karyawan sevesar 0,000 < 0,05 dan nilai F hitung 39,302 > 3,97 sehingga dapat disimpulkan bahwa hipotesis diterima artinya terdapat pengaruh variabel stres kerja secara simutan terhadap kinerja karyawan. sehingga Hasil penelitian ini mendukung hipotesis bahwa terdapat pengaruh stres kerja terhadap kinerja karyawan PT Perkebunan Nusantara VIII kebun Tamabksari

\section{c.2 Hasil Determinasi}

Salah satu Tujuan dalam penelitian ini adalah untuk mengetahui seberapa besar pengaruh stres kerja terhadap kinerja karyawan, untuk menjawab permasalahan tersebut perhitungan menggunakan SPSS versi 23 dengan analisis regresi linier sederhana, adapun hasil perhitungan sebagai berikut :

Tabel 5

Analisis Determinasi

Model Summary

\begin{tabular}{|l|r|r|r|r|}
\hline Model & $\mathrm{R}$ & R Square & Adjusted R Square & $\begin{array}{c}\text { Std. Error of the } \\
\text { Estimate }\end{array}$ \\
\hline 1 &, $597 \mathrm{a}$ &, 356 &, 347 & 2,694 \\
\hline
\end{tabular}

a. Predictors: (Constant), Stres Kerja

Sumber : Hasil olahan spss versi 23

Berdasarkan tabel 5 diatas menunjukan bahwa R square sebesar 0,356 atau 0,356× 100\% $=35,6 \%$ yang merupakan bahwa variabel stres kerja mempengaruhi variabel kinerja karyawan sebesar 35,6\% dan sisanya sebesar 69,9\%.. Besarnya pengaruh variabel stres kerja terhadap Kinerja karyawan sebesar $35,6 \%$ ini pengaruhnya bernilai positif, sebenarnya stres kerja tergantung bagaimana individu menghadapi suatu masalah dalam pekerjaanya. Hal ini sesuai dengan yang dikemukakan oleh Wartono dan Mochtar (2015:170) bahwa Stres kerja tentu akan berpengaruh pada kinerja seseorang (pekerja) tetapi tidak selamanya stres akan merugikan individu atau perusahaan. Stres 
kerja karyawan PT Perkebunan Nusantara VIII Kebun Tambaksari ini bernilai positif. Dalam penelitian ini Indikator yang lebih dominan mempengaruhi kinerja karyawan PT Perkebunan Nusantara VIII Kebun Tambaksari merupakan waktu kerja. Waktu kerja karyawan dimulai pukul 08.00 sampai dengan 16.00 sedangkan waktu kerja lapangan dimulai pukul 07.00 sampai dengan 14.00. Setiap harinya karyawan harus menyelesaikan pekerjaan yang berkaitan dengan hasil kerja yang dilaporkan oleh bagain lapangan terkait dengan jumlah pucuk yang diperoleh dan pengolahan Teh jadi. Adapun Segala bentuk administrasi setiap bulannya memiliki target dimana semua pekerjaan yang berkaitan dengan administrasi harus selesai maksimal setiap tanggal 4. Terkadang Karena Waktu penyelesaian pekerjaan yang diselesaikan berbeda-beda sehingga membuat sebagian karyawan harus menyelesaikan pekerjaan melebihi waktu kerja, bahkan ada beberapa karyawan memilih untuk membawa pekerjaan tersebut kerumah. Setiap karyawan memiliki cara tersendiri untuk menyelesaiakan pekerjaan, tidak bisa dipungkiri bahwa ketika waktu kerja telah selesai tetapi pekerjaan belum selesai menjadi sulit untuk berkonsentrasi. Hilangnya

konsentrasi dalam bekerja terkadang membuat pekerjaan menjadi salah hal ini akan mempengaruhi kualitas hasil kerja. Oleh karena itu sebagaian responden tidak ingin pekerjaanya menumpuk, responden memilih untuk mengerjakan pekerjaanya hari itu juga. Namun berdasarkan hasil observasi bahwa stres kerja bukan menjadi faktor utama yang menyebabkan target perusahaan tidak tercapai, tetapi iklim kerja yang kurang mendukung dalam proses pekerjaan. Hal ini karena suhu terlalu tertinggi membuat cepat lelah dalam bekerja. Sehingga sering kali terjadi kesalahan dalam bekerja. Selain itu sarana dan prasarana yang belum memudahkan dalam proses pelaksaan perkerjaan. hal ini dirasakan oleh responden, Terutama karyawan bagian lapangan bahwa mesin petik yang digunakan sering kali rusak sehingga perkerjaan sering kali terhambat. Iklim kerja mendukung dalam terciptanya peningkatan kinerja karyawan. hal ini didukung oleh hasil penelitian Rahsel (2016:105) bahwa Pentingnya iklim kerja yang menunjang dalam peningkatan kinerja karyawan, maka diperlukan suatu upaya untuk mencipatkan iklim yang kondusif. Dengan semakin kondusifnya iklim maka akan mempengaruhi kinerja karyawan. Stres kerja memang berpengaruh terhadap kinerja karyawan PT Pekerbunan Nusantara VIII, namun stres kerja bukan merupakan faktor utama yang menyebabkan tidak tercapainya target perusahaan hal ini bisa dilihat dari hasil pengolahan data bahwa pengaruh stres kerja terhadap kinerja karyawan hanya sebesar 35,6\%

\section{Kesimpulan}

Penelitian ini bertujuan untuk mengetahui serta menganalisis stres kerja, kinerja karyawan dan pengaruh stres kerja terhadap kinerja karyawan PT Perkebunan 
Nusantara VIII Kebun Tambaksari. Dari identifikasi masalah yang diajukan serta berdasarkan analisis data yang telah dilakukan serta pembahasaan yang telah dikemukakan maka diperoleh kesimpulan sebagai berikut :

a) Berdasarkan hasil penelitian, dapat diambil kesimpulan bahwa tanggapan hasil responden mengenai stres kerja berkategori sedang. Stres kerja dalam penelitian ini diukur berdasarkan 7 indikator yaitu beban kerja, waktu kerja, karakteristik tugas, Hubungan dengan rekan kerja dan atasan, dukungan sarana dan Prasarana, Konflik kerja, dan Kemajuan karier dan diri. pengaruh stres kerja ini bernilai positif, namun Positif dan negatif stres kerja tergantung dari individunya. Bagaimana individu tersebut dapat menilai sesuatu sebagai stres atau bukan, tentu stres kerja akan mempengaruhi dalam proses pelaksanaan pekerjaan, tetapi ketika individu dapat mengelola stres tersebut maka stres kerja akan bernilai positif namun ketika stres yang dialami melebihi kemampuan individu tersebut maka akan benilai negatif.

b) Berdasarkan hasil analisis bahwa kinerja karyawan PT Perkebunan Nusantara VIII Kebun Tambaksari berada dikategori sedang. Dalam penelitian ini kinerja diukur dengan kualitas hasil kerja, kuantitas hasil kerja, ketepatan waktu, kehadiran serta dampak interpersonal. Hal ini menunjukan bahwa secara umum kinerja karayawan sudah cukup baik. Karyawan merasa bahwa jumlah hasil kerja telah memenuhi tuntutan perusahaan serta melaksanakan waktu dengan tidak menunda-nunda. Hal ini membuktikan bahwa kinerja karyawan PT Perkebunan Nusantara VIII Kebun Tambaksari sudah baik.

c) Berdasarkan hasil analisis serta pembahasan stres kerja memiliki pengaruh terhadap kinerja karyawan. Hal ini dibuktikan dengan uji determinasi bahwa pengaruh stres kerja terhadp kinerja karywan PT Perkebunan Nusantara VIII Kebun Tambaksari sebesar 0,356atau 35,6\%. Artinya terdapat pengaruh yang sebesar 35,6\% mempengaruhi variabel kinerja karyawan sedangkan sisianya $64,4 \%$ dipengaruhi oleh faktor yang tidak diteliti dalam penelitian ini.

\section{Referensi}

Ananda dan Sunuharyo. 2018. Jurnal. Pengaruh karakteristik individu dan karakteristik pekerjaan terhadap kinerja karyawan dengan variabel mediator motivasi kerja karyawan.(Studi Pada Karyawan PT Petrokimia Gresik) Vol. 58 No. 1 Mei

Asih,2015.Pengaruh keperibadian dan stres kerja terhadap kinerja pegawai Sekolah Tinggi Penerbangan Indonesia (STPI) Curug Tanggerang. Vol.10 No.1 Februari 2015-47

Aslihah. 2012. Pengaruh Stres Kerja terhadap kinerja karyawan di Koperasi Syari'ah Binama semarang: Universitas Islam Negeri Walisongo Semarang

Burhan. 2005. Metodologi Penelitian Kuantitatif.Jakarta:kencana prenada Media Grup

Filanisa, Ira .2017. pengaruh stres kerja dan jam kerja shifting terhadap kinerja karyawan PT. Infomedia Sokusi Humanika Bandung: Universitas Widyatama 
Indasari, Meithiana.2017.Kepuasaan dan Kinerja Karyawan.Sidoarjo:Indo Mediapusaka Jayanti Rika \& Maulidina.2015.Jurnal. Pengaruh stres kerja terhadap kinerja Pegawai Pada PDAM Titranasi Cabang SEI Agul Medan. Vol 04, No 01,2015-62

Komarudin.2018.Jurnal. Hubungan stres kerja dengan Kinerja Pegawai Pada PT Herona Express kantor pusat Pamulang: Vol.6,No 1,Januari 2018-73

Mu'ah,Masram.2017. Manajemen Sumber Daya Manusia Profesional, Sidoarjo : Zifatama Publisher

Mangkunegara Anwar prabu, 2014. Evaluasi kinerja SDM, Bandung : PT Refika Aditama Marjuni sukmawati,2015.Manajemen Sumber daya manusia, Makassar :CV.Sah Media

Priyonto,2014. Konsep Manajemen Stres, Yogyakarta: Nuha medika

Riandy. 2016. Pengaruh stres kerja terhadap kinerja karyawan Pada PT Borneo Laboratorium inspeksi dan surveyor di samarinada vol.4 No 4-1059

Rahsel,Yoeyong. 2016. Pengaruh ilkim kerja terhadap kinerja pegawai administrasi pusat Universitas Padajajaran Bandung (studi pada bagaian Admistrasi Umum Unpad) vol.2 No 1 Januari 2016

Wartono,Tri.2017. Pengaruh Stres Kerja Terhadap Kinerja Karyawan. Studi Pada Karyawan Majalah Mother and Baby, Vol 4

Sugiyono.2016. Metode Penelitian Administrasi Bandung: Alfabeta

Wijaya,Candra.2017. Perilaku Organisasi. Medan. Lembaga Peduli Pengembangan Pendidikan Indonesia (LPPPI)

Wijono,Sutarto.2010.Psikologi Industri dan Organisasi. Jakarta. Prenadamedia

\section{Grup}

Wijono,Sutarto.2018. Kepemimpinan dalam presepktif organisasi.Jakarta Prenadamedia Grup 